\title{
O nascimento do Brasil: revisão de um paradigma historiográfico
}

João Pacheco de Oliveira

\section{(2) OpenEdition \\ 1 Journals}

Edição electrónica

URL: http://journals.openedition.org/aa/758

DOI: 10.4000/aa.758

ISSN: 2357-738X

Editora

Programa de Pós-Graduação em Antropologia Social (UnB)

\section{Edição impressa}

Data de publição: 1 junho 2010

Paginação: 11-40

ISSN: 0102-4302

\section{Refêrencia eletrónica}

João Pacheco de Oliveira, «O nascimento do Brasil: revisão de um paradigma historiográfıco», Anuário Antropológico [Online], v.35 n.1 | 2010, posto online no dia 07 outubro 2015, consultado o 28 abril 2021. URL: http://journals.openedition.org/aa/758 ; DOI: https://doi.org/10.4000/aa.758

\section{(c) (i) (9)}

Anuário Antropológico is licensed under a Creative Commons Atribuição-Uso Não-Comercial-Proibição de realização de Obras Derivadas 4.0 International. 


\title{
O Nascimento do Brasil: Revisão de um paradigma historiográfico*
}

\author{
João Pacheco de Oliveira \\ Museu Nacional/UFRJ
}

\section{Introdução}

Eu gostaria de tomar como ponto de partida o exato lugar em que nos encontramos neste momento: Porto Seguro, sul da Bahia. Atualmente é o polo turístico mais importante do nordeste, a chamada "costa do descobrimento". Local de grande significação histórica, aqui está o marco zero, dizem as placas e os out-doors, do nascimento disto que chamamos Brasil.

Ocasião que me parece muito adequada para propor outra leitura da História de nosso país e de sua relação com os povos autóctones. Não basta mudar as valorações da narrativa convencional, informando às crianças e à opinião pública que os índios não são inferiores, primitivos, traiçoeiros ou indolentes. As nossas etnografias estão repletas de exemplos belíssimos da humanidade dos indígenas, da elevação de seus valores éticos e estéticos, da sofisticação de seus conhecimentos. Quando tentamos levar tudo isto a um público mais amplo, seja através de entrevistas, livros didáticos ou de filmes e exposições, somos apenas pontualmente ouvidos, pois os novos dados e as imagens acabam por ser incorporados a uma estrutura narrativa que lhes é totalmente adversa, montada para excluir ou ressignificar informações que contrariem seus pressupostos.

Não me refiro aqui apenas àqueles que estão colocados no rol dos que necessitam de informação (o público comum), mas sobretudo na esfera dos que sabem, dos que são portadores de diplomas e detentores de conhecimentos socialmente valorizados. As diferenças de formações disciplinares produzem variações de pouca significação, o que permanece são as pressuposições subjacentes, que se cristalizam em "sistemas de verdades", que constituem a parte invisível e não-verbalizada desse iceberg. Mesmo quando eventualmente as posturas éticas ou políticas dessas pessoas conflitam com tais "verdades", estas raramente são revistas, porque asseguram a base e o ponto de equilíbrio da totalidade da sua interpretação.

Estamos em um congresso que reúne a comunidade (científica, profissional) dos antropólogos e no qual comparecem, felizmente, alguns indígenas, que são os nossos interlocutores na situação etnográfica e na produção de interpretações 
etnológicas. Mas a narrativa histórica não é escrita primordialmente por antropólogos, etnólogos ou indígenas, nem estes vivem isolados, imunes a saberes que não lhes são próprios e que provem de outras disciplinas.

É fundamental assim que façamos aqui um esforço de crítica a esquemas analíticos e narrativos que são aplicados em geral para compreender a presença indígena no Brasil atual. Trata-se de uma história de interpretações do Brasil baseadas em categorias coloniais e imagens reificadoras que precisam ser revistas, pois os instrumentos de essencialização com que operam não servem mais nem para a pesquisa científica, nem contribuem para o aumento do protagonismo indígena ou o estabelecimento de melhores políticas públicas. É imprescindível implodir esta narrativa, anular os seus efeitos de verdade e instituir outra chave de leitura da história do país. ${ }^{1}$

\section{Rompendo com a inocência}

A narrativa habitual sobre a história do Brasil traz consigo duas opções estilísticas vinculadas ao paradigma evolucionista e que merecem ser comentadas. A primeira é o papel do acaso. O relato sobre as condições precárias e aventurosas da navegação no final do século XV ajudou a criar expectativas bastante equivocadas sobre a descoberta do Brasil e o relacionamento dos europeus com as populações autóctones. Por extensão metonímica, o encontro foi muitas vezes descrito como uma obra do acaso, algo quase acidental e fortuito, algo que, em termos de narrativa, contém sempre potencialmente uma ponta de ironia e non sense, terreno fértil para o exotismo.

Aqui entra o segundo ponto. A busca de uma racionalidade leva a localizar os personagens e os eventos concretos em um processo maior, que é a expansão do mundo europeu no continente americano, integrando uma narrativa mais abrangente, supostamente inexorável e de sentido unívoco. O casual desemboca na fatalidade, que anula completamente os agentes históricos, sem sequer sentir a necessidade de justificá-los ou absolvê-los (pois a narrativa flui de um único prisma, o europeu, compartilhado pelo narrador e seus ouvintes). Tudo concorre para criar a certeza sobre a condição efêmera daquele encontro e a pequena importância dos indígenas na conformação do mundo colonial que irá se instaurar na chamada América Portuguesa.

Um instrumento aparentemente cômodo é a noção de "ciclo", que terá como função descrever a diversidade de formas econômicas e societárias registradas na história. Mas para utilizá-lo é preciso alojar-se no interior de um processo abstrato, cumulativo e ascendente, de sentido teleológico. A história torna-se uma sucessão de ciclos (agrícolas e extrativistas) - o pau-brasil, o açúcar, o couro, as drogas do sertão, os minérios preciosos, o café e a borracha. Mais tarde seria a vez das 
distintas fases da industrialização; hoje em dia seriam as etapas da globalização... O interesse do estudioso em cada uma dessas formas converge para o momento em que ela penetra numa zona de intensa visibilidade, tornando-se o modo de produção dominante e oferecendo ao investigador fontes extensas e variadas. Fora desse momento de "apogeu" os relatos são sempre simplificadores, atribuindo-lhe a condição de "resíduos" que estão em vias de desaparecimento.

Há um lugar e um momento claramente atribuídos ao indígena nessa narrativa: eles seriam anteriores ao Brasil e a narrativa sobre eles deveria ser feita preferencialmente antes da colonização. Uma vez esta iniciada, os indígenas só poderiam ser concebidos como flores que fenecem, que precisam ser descritas e compreendidas antes que murchem e desapareçam. A superioridade tecnológica e militar dos colonizadores, as violências e as epidemias dariam conta de explicar a sua extinção.

De nada adianta aplicar teorias radicalmente novas nem propor uma reforma terminológica se o "sistema de verdades" em que se assenta a narrativa convencional não for objeto de uma revisão crítica. O termo "descoberta” é equívoco e inaplicável, mas a sua substituição por eufemismos como "encontro de culturas" ou "encontro de civilizações” pode ser inócua se deixar intocadas as regras de sintaxe e os pressupostos do discurso colonial. O mesmo destino, aliás, estará reservado a um antidiscurso (como falar em "invasão") se não conduzir a uma crítica profunda das certezas e das atitudes naturalizadas na narrativa convencional.

Uma constatação imprescindível é a de que essa narrativa que aqui combatemos não foi de maneira alguma contemporânea aos fatos do século XVI, mas uma produção do século XIX - não do universo renascentista ou do mundo colonial, mas do evolucionismo científico e no Brasil sobretudo do Segundo Império. Desde então reina como absoluta entre pensadores de direita ou de esquerda, entre historiadores, sociólogos e filósofos.

Caminha, em sua famosa carta, não falava em descobrimento, mas em "achamento" (algo que não exclui a intencionalidade). Ele também não considerava os autóctones como perigosos, improdutivos ou incapazes. Os cronistas do século XVI, mesmo quando com interesses diretamente antagônicos aos indígenas, não deixaram de dar conta da extensão numérica e da diversidade dos autóctones. ${ }^{2}$ Administradores, missionários e particulares ocuparam-se extensamente em seus relatos de muitas "nações de gentios". A colônia seria inviável sem estabelecer com eles um modus vivendi.

Quase um século e meio depois do "achamento" do Brasil, o Príncipe de Orange, Maurício de Nassau, ao retornar à Europa depois de um longo período em Pernambuco, escrevia à Companhia das Índias Ocidentais afirmando que o destino da colônia dependeria fundamentalmente "das relações que os administradores 
viessem a estabelecer com os nativos". ${ }^{3}$ Tal avaliação não decorria da imaginação de um navegante quinhentista ao encontrar uma terra longínqua povoada por criaturas nunca vistas pelos europeus, mas sim do administrador da maior área de plantation escravista da América, principal fornecedora do açúcar ao mercado europeu, cujas riquezas e potencialidades eram objeto de planos e disputas pelas metrópoles coloniais.

O reconhecimento da importância da presença indígena na colônia não era uma particularidade dos holandeses, mas podia ser encontrado nos minuciosos trabalhos de cartógrafos portugueses, nos quais se tornava evidente que os colonizadores na primeira metade do século XVII só mantinham controle sobre a faixa litorânea. O mapa de Albernas (Figura1), datado de 1631, mostra nitidamente o controle territorial exercido por "nações indígenas", algumas com nomes genéricos (como os "Tapuias"), outras melhor identificadas (como os Potiguaras, os Tupinambás, os Tupiniquins, entre outros). Ainda hoje os antropólogos, ao realizarem laudos periciais, têm que despender várias páginas de argumentação para explicar a juízes e a advogados, assim como a jornalistas e à opinião pública, que os índios não são "nômades" que "perambulam" a esmo pelo espaço geográfico, sem possuírem qualquer noção de seu território. Algo que os cartógrafos portugueses do XVII já bem sabiam! ${ }^{4}$

É só no Segundo Império, quando o projeto de nação se elabora a partir dos debates sobre a migração e o fim da escravatura negra, sem atribuir aos indígenas qualquer outra função que a de símbolo da terra, que essa narrativa se estrutura, ganhando autor (a monumental história geral de Varnhagen [1978]) e instituição mantenedora (o IHGB do Rio de Janeiro e, posteriormente, suas sedes provinciais), internalizando-se no pensamento da elite letrada. ${ }^{5}$

\section{$O$ regime das feitorias}

Na primeira metade do século XVI as áreas costeiras do Atlântico na América Meridional eram intensamente frequentadas por portugueses e franceses, com alguma presença de espanhóis. Obter a simpatia e a colaboração dos nativos era a principal preocupação de ambos os lados.

O regime das feitorias designa a primeira situação histórica em que as populações autóctones e os europeus foram colocados regularmente em interação. A produção era primordialmente o pau-brasil e a economia estava baseada no escambo. A atenção era centralizada no comércio, o território sendo apenas objeto de disputas setoriais.

A relação entre colonizadores e colonizados não era rigidamente dualista, mas sim bipartida e incluía de fato quatro elementos: os portugueses, seus inimigos franceses, os indígenas que se aliavam aos portugueses, os indígenas que se alia- 


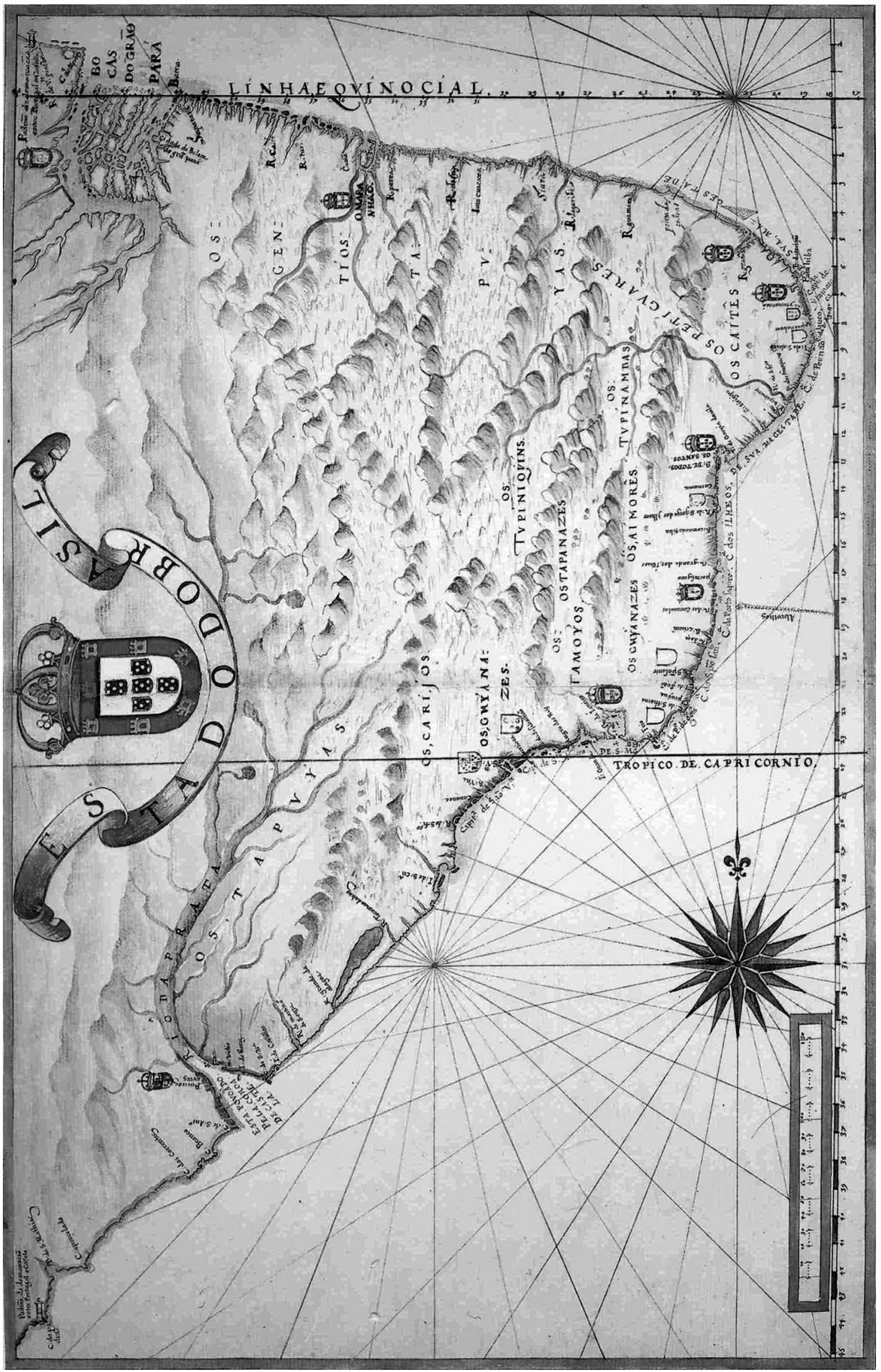


vam aos franceses. O conflito entre os europeus apropriava-se e sobrepunha-se aos conflitos entre os próprios Tupis, oferecendo para algumas nações de gentios um código que lhes era familiar e prenhe de significações.

Advêm desse contexto o registro de narrativas e representações simpáticas quanto aos indígenas do Brasil. A primeira representação gráfica de indígenas em Portugal ocorreu na Epifania do altar-mor da catedral de Viseu, obra pintada por Vasco Fernandes em torno de 1505 (Figura 2). Ali, um dos reis magos era figurado como um tupiniquim, possivelmente algo inspirado na carta de Caminha e na descrição de um indígena que acompanhou atentamente a missa rezada por Frei Henrique de Coimbra (vide Belluzzo, 2000).

No próprio contexto europeu a presença de chefes indígenas aliados conferia prestígio aos monarcas, que os tratavam muito bem e os exibiam nas cortes francesa e portuguesa, designando-os inclusive como de "reis". A peça em madeira, intitulada Medallion du Roi Sauvage (Figura 3), é uma das diversas figuras encontradas na igreja de Saint-Jacques, localizada em Dieppe, possivelmente datada de 1535. Várias imagens também resultaram da visita do Imperador Francisco I à cidade de Rouen, onde foi recebido com uma encenação da vida indígena, realizada por índios e marinheiros, no episódio que ficou conhecido como "uma festa brasileira" (Figura 4) eque antecedeu de pouco à tentativa de criação de uma colônia francesa na Baía de Guanabara. ${ }^{7}$

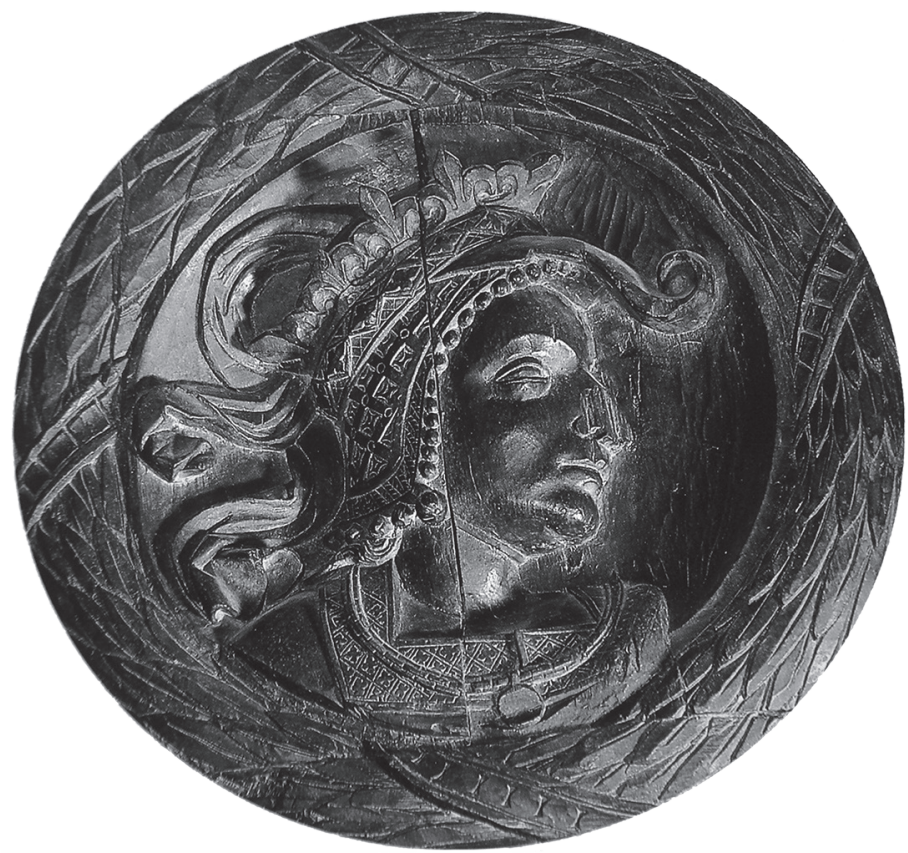

Figura 3 


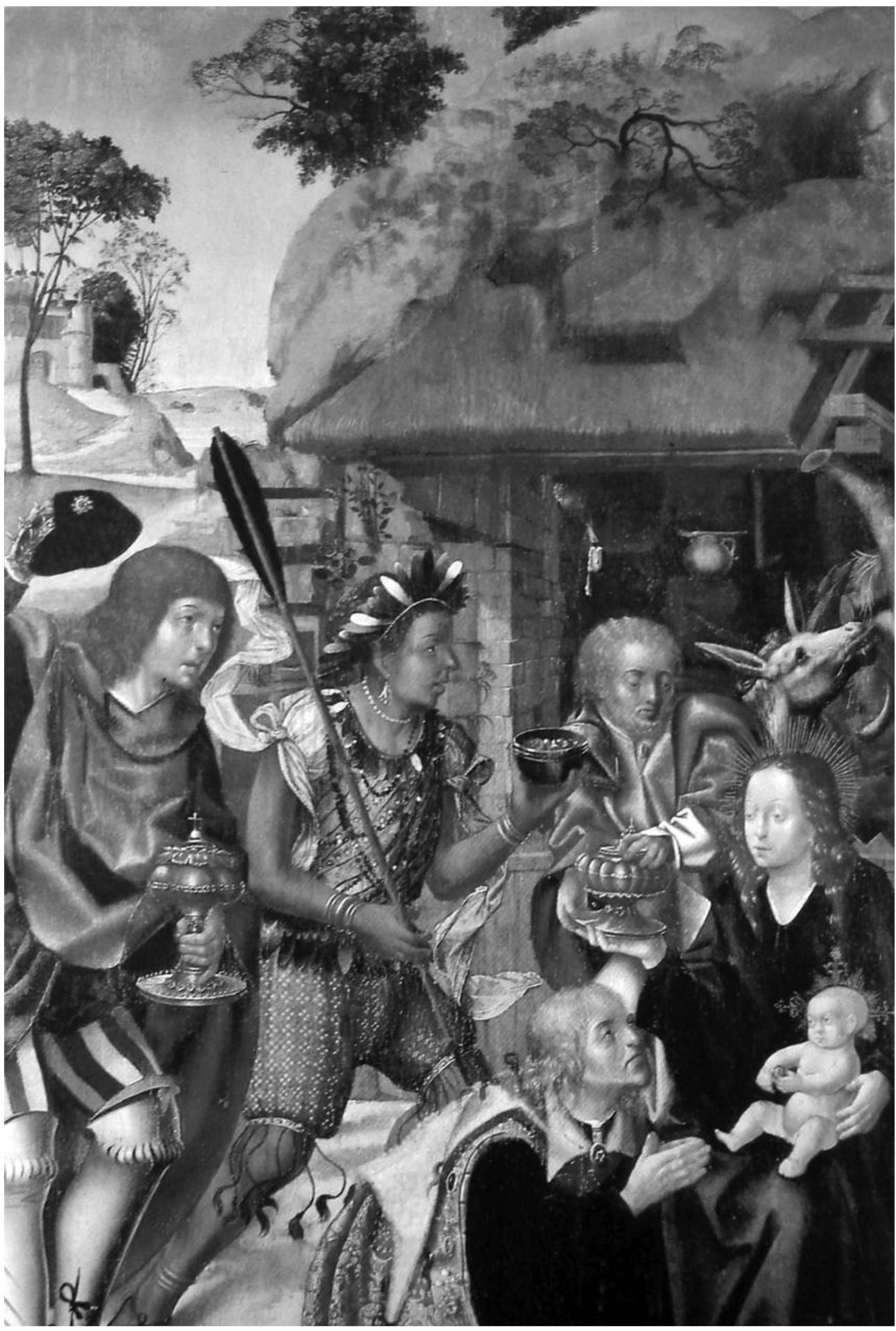

Figura 2 
Ao apontarmos a fragilidade da dominação, não estamos de maneira alguma endossando uma visão idílica da colonização portuguesa ou nos atendo apenas à dimensão local. Existiu nessa situação histórica uma rede de interdependências dos colonizadores com os indígenas que resultava de articulações mais amplas entre os poderes coloniais. Uma representação relativamente positiva dos indígenas e a disposição em estabelecer alianças com eles estavam articuladas com o interesse no comércio de pau-brasil e de animais exóticos. Outras iniciativas econômicas exigiriam uma capacidade efetiva bem maior desses reinos em investir homens e recursos materiais nas colônias.

O jogo propiciado pelos antagonismos e pelas reciprocidades não excluía assimetrias, manipulações nem avaliações divergentes. As relações de parentesco criadas pelos "lançados" (degredados, náufragos e desertores) com os nativos serviram para instituir as bases de uma estrutura de poder imprescindível aos colonizadores, bem como foram úteis para legitimar posteriormente o domínio português. A própria carta de Caminha já deixava claras as potencialidades econômicas da terra (não só para o escambo, mas também a qualidade das águas, da terra e do clima, pensando assim no estabelecimento de lavouras). Tão pouco ele esquecia de indicar a El Rey a importância de uma ideologia que justificasse e enaltecesse a colonização, propondo como essencial o estabelecimento de uma tutela cristã sobre os nativos. ${ }^{8}$

\section{O paradigma da colonização}

Ao fim de quatro décadas, a lista de povoações portuguesas na "Costa do PauBrasil” era bem reduzida: Igarassu, Olinda, Ilhéus, Porto Seguro, Santa Cruz (hoje Cabrália), Vitória (Espírito Santo), São Vicente (reedificada em outro local) e Santos. A maioria dessas povoações encontrava-se com frequência sitiada por indígenas hostis e sem condições de expandir (ou até manter) o núcleo inicial. Os franceses, por sua vez, mantinham comércio regular e algumas alianças com indígenas no Rio de Janeiro, na ilha de Itamaracá, na Paraíba e em Sergipe.

O momento de fundação da colônia não foi de maneira alguma o ano de 1500 e de seu "achamento", mas a implantação de um governo-geral, a instalação de uma sede e de um aparato administrativo na Bahia de Todos os Santos e a definição de um projeto civilizatório. É possível visualizar com nitidez a mudança de postura da Coroa portuguesa quanto ao Brasil no Regimento de 17/12/1548, outorgado a Tomé de Souza, primeiro governador-geral. Não se tratava mais de aproveitar dos jardins do paraíso, mas de tomar providências urgentes para ganhar uma guerra (que estava sendo parcialmente perdida) contra os indígenas e seus eventuais aliados franceses. 


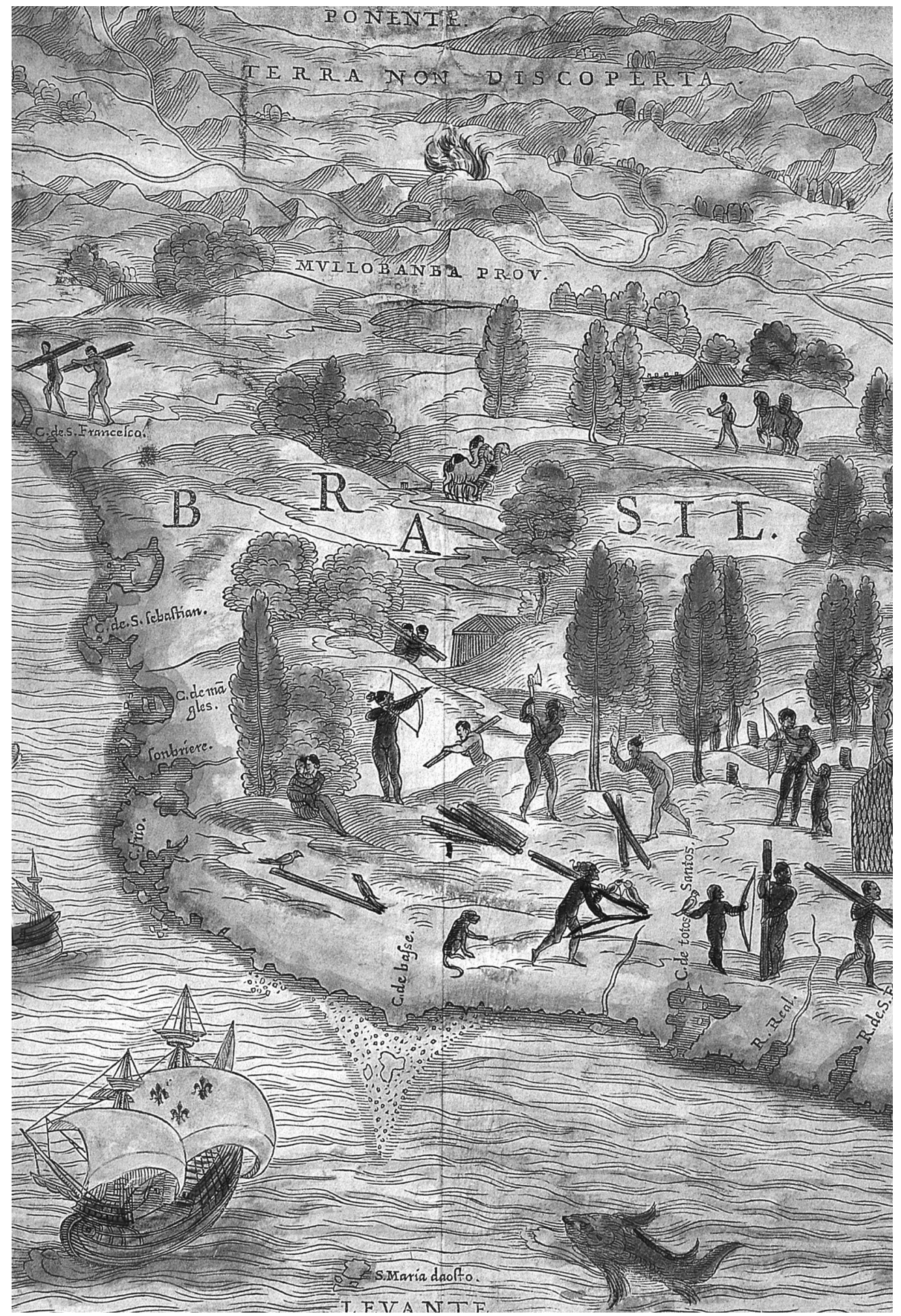

Figura 4 
As orientações eram no sentido de ampliar o poder defensivo dos núcleos já existentes, com a fortificação de vilas e povoações. Os próprios engenhos e fazendas deveriam ser dotados de estruturas defensivas, como torres e casas-fortes. Todos os moradores que possuíssem casa, terras ou embarcações deveriam dispor de armamento próprio. Era rigorosamente interditada a venda aos "gentios" de qualquer tipo de arma defensiva ou ofensiva (arcabuzes, espingardas, pólvora e munições, bestas, lanças, espadas ou punhais). Para a penetração nos sertões através dos rios foi autorizada a construção de embarcações a remo dotadas de peças de artilharia à custa da Fazenda Real (Couto, 1995:233).

O Regimento recomendava que aos índios aliados fosse dispensado um bom tratamento, proibindo, sob pena de açoite, que os moradores fossem nas aldeias para recrutar trabalhadores ou para comerciar sem autorização expressa do governador. O que a Coroa pretendia era não estimular levantamentos e revoltas por parte dos indígenas, nem fazer que os autóctones viessem a pender para o lado dos franceses.

El Rey enfatizava a importância da conversão ao catolicismo da população nativa. Contudo, para os que se opusessem ao domínio português - que eram enquadrados no crime de "traição" - o Regimento prescrevia um tratamento muito duro. Os Tupinambás eram diretamente citados, recomendando-se que todos aqueles que se voltassem contra os portugueses fossem "castigados com muito rigor [...] destruindo-lhes suas aldeias e povoações e matando e cativando aquela parte deles que vos parecer que basta para seu castigo e exemplo”. Já estava aí aplicada a figura da "guerra justa".

À diferença da situação anterior, onde em que a presença portuguesa era descontínua e convivia com instituições bastante heterogêneas, o objetivo básico passou a ser o controle territorial, criando uma unidade entre núcleos dispersos e vulneráveis e implantando as instituições políticas europeias. O que El Rey tinha em mira era estabelecer a plena e total submissão da população autóctone, fazendo a guerra aos que não aceitavam o domínio português e retirando dos franceses qualquer respaldo para as suas iniciativas.

Não é assim que a versão consagrada da história descreve. Acompanhando as fontes oficiais da época, que raciocinavam em termos diplomáticos e do Tratado de Tordesilhas, os franceses eram qualificados como "invasores" e os indígenas que com eles estabeleciam alianças como "traidores". A este historicismo ingênuo veio paradoxalmente associar-se um "presentismo" do século XIX, bastante etnocêntrico, e que não reconhecia aos indígenas qualquer protagonismo dos indígenas no relacionamento com as nações europeias. Uma leitura unilateral das fontes predominava ao enunciar os objetivos da atuação portuguesa, fixando como rationalia apenas a expulsão dos franceses. O lugar que os indígenas poderiam assumir seria 
apenas exclusivamente o de aliados militares dos portugueses, combatendo os "invasores" franceses e os indígenas ("traidores") que lhes eram associados.

Os regimentos e os documentos administrativos sugerem uma interpretação bastante diferente! Portugal não mais desejava mais ter os indígenas puramente como parceiros comerciais ou aliados, mas sim como vassalos. Tratava-se não apenas de propiciar um comércio lucrativo, mas de fundar uma colônia portuguesa na América Meridional, o que envolveria necessariamente controle do território e povoamento.

Para investir na colônia recursos de muito maior monta, havia que ter em suas mãos o governo dos índios e a soberania exclusiva do território, expulsando os rivais franceses e implantando modalidades estáveis de geração de riquezas. Estas inclusive deveriam propiciar aos moradores, em pouco tempo, uma relativa autonomia em face do Tesouro Real. A materialização dessa nova forma econômica foi o estabelecimento de lavouras de cana e engenhos em terras doadas enquanto sesmarias aos colonos.

Se o lado mais heróico da fundação da colônia, aquele que seria apropriado e celebrado pela narrativa convencional, foi o das lutas contra os franceses, existe uma face velada, que decorre de uma avaliação da Coroa quanto à necessidade e ao desejo de uma submissão definitiva das populações autóctones.

\section{A guerra de conquista}

No episódio da Guanabara isto se torna claríssimo. A França Antártica durou cerca de 4 anos. Ela foi destruída por uma armada real composta de 8 ou 10 caravelas (Couto, 1995: 245-249) para isto especificamente mobilizadas, e que em 1560 vieram para arrasar as fortificações francesas, executar os oficiais e fazer prisioneiros (enviados a Lisboa). Foram distribuídas aos portugueses 50 cartas de sesmarias.

A tentativa de criar uma colônia francesa no litoral do Rio de Janeiro acabou aí. $\mathrm{O}$ que se seguiu foi a luta dos portugueses contra os Tamoios, que acolheram em suas aldeias alguns poucos soldados franceses que teriam logrado escapar do cerco ao Forte Coligny.

A segunda expedição, em 1565, foi integrada principalmente por indígenas provenientes da Bahia, do Espírito Santo e de São Paulo que lançaram as bases de uma povoação no Morro Cara de Cão. Só mais tarde, em 20 de janeiro, com a chegada do governador-geral e de algumas caravelas, é que foi iniciado o ataque às posições dos Tamoios, que foram desalojados de seus sítios e vieram a ter ocupadas as suas localizações (para as cercanias das quais foi logo depois transferida a cidade recém-fundada. Foram presos e enforcados menos de uma dezena de franceses que viviam entre os indígenas. O principal chefe, Aimbirê, foi morto durante os combates e seus liderados transformados em prisioneiros, enquanto um outro grupo 
de indígenas, bastante extenso, bateu em retirada por mar em cerca de 180 canoas para a região de Cabo Frio.

A terceira expedição, realizada quase dez anos depois e composta apenas por moradores e indígenas, foi dirigida unicamente contra os Tamoios que haviam fugido da Guanabara. Dela resultou a morte dos últimos líderes e 4.000 prisioneiros, que foram levados como cativos para as recém-instaladas fazendas do Rio de Janeiro. Apoiando-nos nos dados de população oferecidos por Gândavo (1995:67-123), é possível concluir que este número de cativos representava mais de cinco vezes os residentes portugueses naquele local.

Todas as demais guerras empreendidas por Mem de Sá contra os indígenas estavam umbilicalmente ligadas ao avanço da colonização e não tiveram entre as suas motivações uma conexão central com outros invasores europeus. Durante duas décadas, o terceiro governador-geral moveu guerras (decretadas como "justas") contra os Tupinambás no Recôncavo baiano; os Tupiniquins, no sul da Bahia e Espírito Santo; os Caetés, em Pernambuco. Nas décadas seguintes novas "guerras justas" foram dirigidas por outros governadores contra os Aymorés, em Porto Seguro e Ilhéus, e contra os Potiguaras, da Paraíba e do Rio Grande do Norte.

A ferocidade da ação repressiva revelava uma clara intenção de exemplaridade, já anunciada no Regimento outorgado a Tomé de Sousa. A campanha realizada por Mem de Sá contra os Tupiniquins deixa isto nítido. Em 1560 o governador recebeu notícias de que "o gentio Tupiniquim da capitania de Ilhéus se alevantara e tinha morto muitos cristãos e destruído e queimado todos os engenhos [...] e os moradores estavam cercados”. Para lá rumou, levando indígenas das missões, além de soldados portugueses, "indo dar em uma aldeia que estava a sete léguas [42km] da vila, em um alto pequeno, toda cercada d'água”. Após esta descrição quase bucólica, ele entra de chofre no relato da ação militar: "[...] a destruí e matei todos os que quiseram resistir e a vinda vim queimando e destruindo todas as aldeias que ficaram atrás”. Porém, mais indígenas tupiniquins lhe apareceram, e foram logo imprensados para o mar, onde pelejaram e foram mortos por outros índios, num episódio que se tornou conhecido como "a batalha dos nadadores". "Nenhum Tupiniquim ficou vivo, e todos os trouxeram a terra e os puseram ao longo da praia, por ordem que tomavam os corpos perto de uma légua”.

Os indígenas que saíam dos montes e das brenhas vinham "a pedir misericórdia e lhes dei pazes com condição de que haviam de ser vassalos de sua alteza e pagar tributo e tornar a fazer os engenhos". Em espaço de 30 dias toda a terra ficou pacificada! Nos anos seguintes, os cronistas destacam que os Tupiniquins se transformaram no mais fiel aliado dos portugueses, vindo a compor a maioria da tropa que derrotou os Tamoios na Guanabara. 


\section{A fundação da Colônia}

A capitania da Bahia, como sede do governo geral, foi o lugar onde mais nitidamente se expressaram as intenções do projeto colonizador. Os moradores da antiga vila do Pereira vieram a receber não apenas o governador, mas todo um staff dirigente, que incluía ouvidor, provedor, missionários, soldados, um mestre-de-obras e artífices. Eram 600 colonos e 400 degredados (Sousa, op.cit.:89-101), que em pouco tempo tiveram que produzir toda uma infraestrutura governativa (Casa de Governo, Audiência, Câmara, Alfândega, Fazenda, fortes e casernas, cadeia, a capela de Nossa Senhora da Conceição, armazéns, ferrarias e habitações para os colonos). Tudo isso em terreno previamente cercado e dotado de baluartes com artilharia.

A população da Bahia em poucos anos aumentou quase seis vezes. Pero de Magalhães Gândavo (1995) estimou 1.200 vizinhos, pouco mais de 6 mil pessoas, na década de 1570. Em 1585 este número quase dobrou, os portugueses chegando a 11 mil, enquanto a população total correspondia a 22 mil (Anchieta, 1988:418-431). Em 1590, segundo outra fonte, a capitania real teria quase 30 mil moradores. ${ }^{9}$

O governador concedeu sesmarias de terras para os seus principais colaboradores, que nos anos seguintes buscaram implantar nas imediações fazendas e engenhos. O número de engenhos também disparou, indo de apenas um, que precedia à fundação da cidade, a 18 em 1570, 46 em 1585 e 50 em 1590 (Couto, 1995:287).

Entre outros benefícios, Tomé de Souza concedeu aos jesuítas em 1550 uma sesmaria onde foi erguido um colégio para órfãos, abrigando cerca de 60 meninos - a maioria indígenas (id., ibid.:320). Nos primeiros anos da presença jesuíta não há informação sobre o assentamento de aldeias. Antes de 1557 há menção a apenas duas aldeias, uma delas (São Sebastião) vizinha à cidade, outra a cerca de 9 quilômetros (Nossa Senhora, no Rio Vermelho). Em 1557 foram criadas mais duas aldeias, com uma população total (as quatro) de 10 mil pessoas. O número de aldeias foi num crescendo, em 1562 chegando a 11, e nelas residindo 34 mil indígenas (Marchant, 1980:95).

Foi indiscutivelmente com base no trabalho indígena que esse crescimento demográfico, econômico e territorial ocorreu. As novas aldeias criadas acompanhavam a implantação de fazendas e engenhos, dispondo-se de 20 a até $180 \mathrm{~km}$ de Salvador. Os índios assentados nas aldeias jesuíticas correspondiam por si só a mais de cinco vezes o conjunto de moradores portugueses anotados por Gândavo para a década seguinte. ${ }^{10}$

Em 1662 uma epidemia de varíola vitimou cerca de 30 mil pessoas na Bahia, em sua grande maioria nas aldeias missionárias. Há notícias também de outro surto epidêmico ocorrido em 1584. As doenças e as fugas resultantes do descontenta- 
mento com a nova situação acarretaram uma enorme diminuição do contingente de indígenas da capitania. Segundo Gândavo, em 1576 seriam somente 8 mil. O número de escravos africanos em 1585, de acordo com o padre Anchieta, correspondia a pouco mais de $1 / 3$ do número de indígenas.

As investigações históricas recentes têm revelado que o trabalho indígena foi a mão-de-obra fundamental no Brasil no século XVI. Baseando-se no estudo da documentação sobre o engenho real Sergipe, Stuart Schwartz mostrou que no ano de 1572 a mão-de-obra indígena representava 93\%, escravos africanos perfazendo o restante. Entre os indígenas, o mais avultado contingente era dos Tupinambás, seguido pelos Caetés e Tapuias, havendo registro de indivíduos procedentes de populações tão distantes como os Tamoios e os Carijós (vide Schwartz, 1988:60-69).

\section{A conquista de Pernambuco}

Em 1562, em represália à morte do bispo Sardinha e dos ocupantes da embarcação que o conduzia, naufragada seis anos antes (!), o governador declarou "guerra justa” contra os Caetés que ocupavam o litoral, do norte da Bahia até Pernambuco. Depois de submetidos, tal como ocorrera com os Tupinambás do Recôncavo, os Caetés, sofreram outro flagelo, uma epidemia de varíola que vitimou cerca de 70 mil desses indígenas (Marchant, 1980). Submetido militarmente e vitimado pela varíola, o gentio Caeté da capitania de Pernambuco deixou de oferecer resistência armada aos colonizadores.

Os engenhos existentes em Pernambuco, que eram apenas cinco em 1546, passaram a 23 em 1570 e a 66 em 1585. Por sua vez, a população também cresceu bastante, indo de pouco mais de 3 mil em 1546 para cerca de 8 mil em 1585 (Couto, 1995: 276-277 e 287). Alguns anos antes, Pero de Magalhães de Gândavo observara que nessa capitania "tem muitos escravos índios, que é a principal fazenda da terra. Daqui os levam e compram para outras capitanias, porque há nesta muitos e mais baratos que em toda a Costa" (Figura 5).

O que tais fatos revelam é que a guerra de conquista da "Costa do Pau-Brasil", iniciada com o estabelecimento de um governo geral, teve justamente como finalidade submeter a população autóctone, permitindo o livre acesso e a distribuição das terras que antes ocupavam e mobilizando os seus antigos moradores para o trabalho nos empreendimentos coloniais.

\section{A importância da aliança com os indígenas}

O paradoxal é que o sucesso inicial da colonização dependeu da rede de relações constituída durante o regime das feitorias. Uma figura essencial no contexto anterior era a do intermediário, do lado português, os "lançados", do lado francês, 


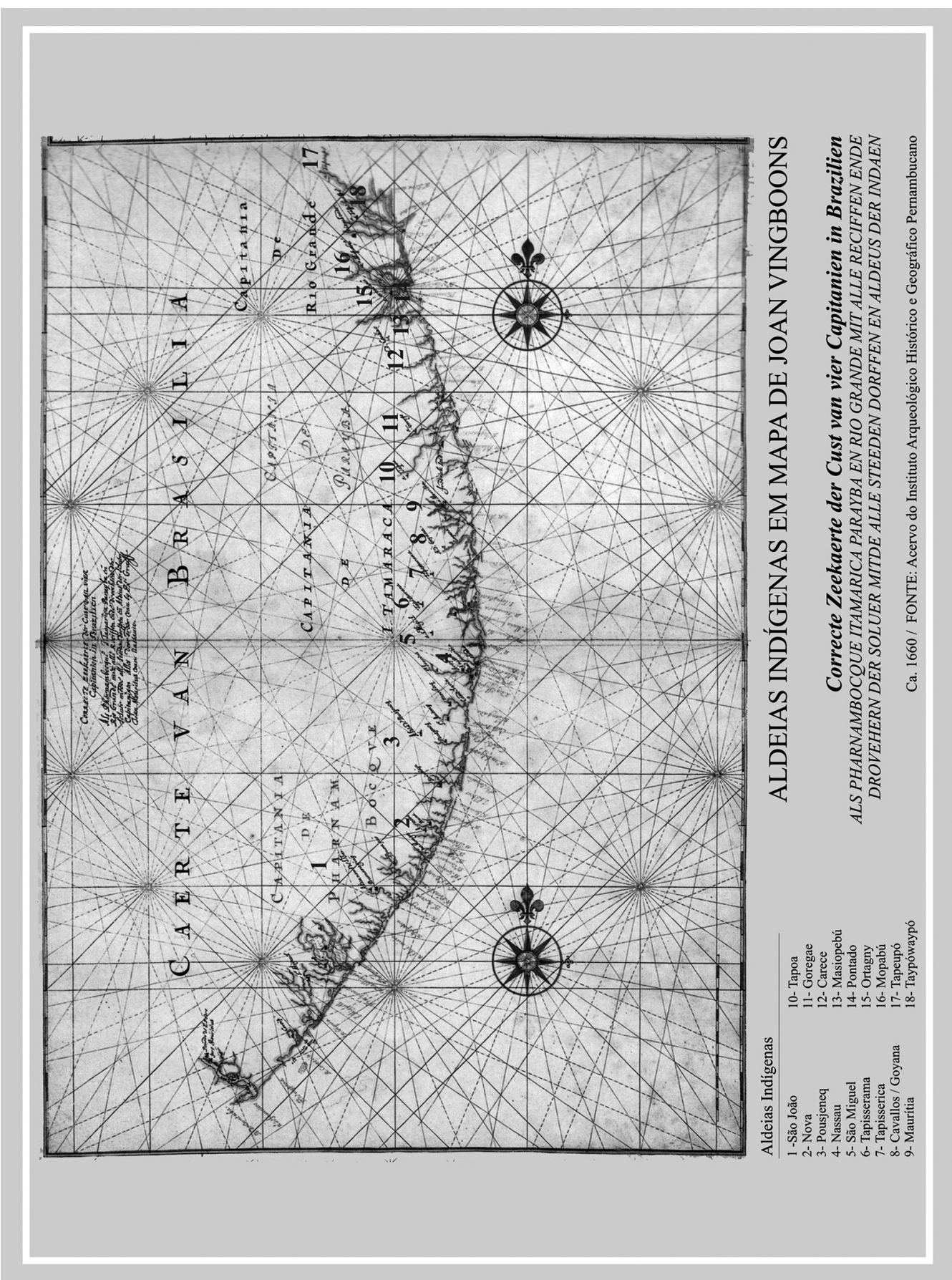

Figura 5 
os truchements. Embora fossem tradutores culturais, aprendendo os idiomas e os costumes nativos, não eram apenas "línguas" (intérpretes), mas sim os operadores práticos das alianças. Contraíam matrimônios com mulheres indígenas, herdando redes de relações políticas e cerimoniais, o que lhes permitia serem agenciadores da produção do pau-brasil e mediadores das relações com os europeus. As famílias que instituíram foram as raízes dos mais antigos moradores da colônia, como em São Paulo, Bahia e Pernambuco. Os próprios ideólogos da colonização, situados na metrópole, nesse momento valorizavam a mestiçagem como estratégia política e de povoamento. ${ }^{11}$

O concurso dos indígenas era então essencial. Isto era reconhecido explicitamente, tendo El Rey enviado em dezembro de 1548 carta a Diogo Álvares, o chamado Caramuru, solicitando que intermediasse a relação com os indígenas e apoiasse a implantação da capital da colônia em Salvador. Antes de regressar a Portugal, Tomé de Souza investiu na condição de cavaleiros três filhos e um genro de Diogo Álvares por relevantes serviços prestados à Coroa (id. ibid.:239-242). Sem a anuência e sem a mão-de-obra das populações autóctones não poderia ser estabelecida a infraestrutura colonial indispensável, incluindo-se nisso desde as construções públicas até o pleno funcionamento dos engenhos.

Há um exemplo similar na capitania de Pernambuco, a mais próspera de todas. Ali os portugueses puderam expandir-se graças a uma aliança com os Tabajaras. Estava em um terreno cedido por estes o primeiro assentamento (Igarassu). Jerônimo de Albuquerque, cunhado do donatário, veio a esposar uma filha do cacique Arcoverde, tendo uma extensa prole, que foi a origem de algumas das mais velhas famílias locais. Com a fundação de Olinda (1535) em terras dos Caetés, instaurouse um conflito que se estenderia por mais de duas décadas. Em algumas ocasiões, os Caetés conseguiram sobrepor-se aos Tabajaras e chegaram até a pôr em cerco Igarassu e Olinda (Staden, 1974[1557]:47-51).

No projeto de colonização da segunda metade do século XVI, os intermediários no tratamento com o gentio não seriam mais os "lançados", e sim os missionários, que não conviviam da mesma forma com os costumes do "gentio" e lhes impunham valores e instituições portuguesas (cristãs). Foram essas figuras preeminentes do projeto colonial que fundaram aldeias, reunindo os autóctones em espaços limitados, encarregando-se de sua civilização e catequese.

Ao chegar à Bahia, o padre Nóbrega ficou impressionado com a generalidade do costume entre os moradores de possuírem nativos como escravos. Isto afrontava a bula papal, "Veritas Ipsa”, feita por Paulo III em 1537, que afirmava que as populações autóctones da América possuíam alma e que não deveriam ser objeto de maus tratos ou escravização. Havia que dar à conquista um fundamento religioso para que 
esta se adaptasse aos parâmetros de uma "guerra justa". ${ }^{12}$ Tratava-se de produzir uma verdadeira conversão do gentio, estipulando como condições inaceitáveis à catequese a continuidade da atuação dos pajés, da poligamia e da antropofagia. ${ }^{13}$

$\mathrm{Na}$ realidade, missionários, moradores e administradores estavam inseridos em uma densa teia de relações de interdependência. A demanda por trabalho indígena nas fazendas e nos engenhos deveria ser atendida primordialmente através dos índios das missões, mediante o pagamento de salários e condições que não desestruturassem a economia das aldeias nem inviabilizasse a catequese.

A expansão de fazendas e engenhos sobre os terrenos habitados pelos indígenas era tornada possível através dos “descimentos" e da criação de aldeias, que reterritorializavam os naturais da terra em espaços mais limitados e sob supervisão dos missionários. Foram dessas aldeias que saíram os contingentes que permitiram o nascimento econômico da colônia, tanto em trabalhos para El Rey, nas obras públicas, quanto para serviços aos particulares. Daí procedeu igualmente uma parte substancial das tropas que combatiam os indígenas que de algum modo se rebelavam contra o domínio português.

Paralelamente a isso, os moradores engendraram alternativas próprias de obtenção de braços para as lavouras. A primeira e mais antiga era por meio das tropas de resgate e da concessão de escravos temporários aos soldados que lutavam nas "guerras justas", a criação de uma espécie de mercado informal de escravos indígenas. Ainda que em alguns momentos as práticas que produziam tal mercado fossem coibidas, na maioria do tempo este era considerado ilegal mas de fato tolerado.

A segunda era o tráfico de escravos africanos, que gerava trabalhadores classificados e transacionados como mercadoria, sem passar portanto pelas regras limitativas que eram aplicadas aos indígenas ("negros da terra”). À medida que a produção do açúcar se expandia, a utilização de escravos africanos passou a ser a opção básica dos plantadores de cana, enquanto o trabalho indígena, a partir do século XVII, era destinado a atividades complementares (como a produção de alimentos, os trabalhos pesados e mais arriscados).

Alguns anos depois, Pero de Magalhães Gândavo, em um texto que buscava estimular a vinda de portugueses para o Brasil, nos propicia um impressionante panorama da colônia no último quartel do século XVI.

As pessoas que no Brasil querem viver, tanto que se fazem moradores da terra, por pobres que sejam, se cada um alcançar dois pares ou meia dúzia de escravos [...] logo tem remédio para a sua sustentação; porque uns lhe pescam caçam, outros lhe fazem mantimentos e fazenda e assim pouco a pouco enriquecem os homens e vivem mais honradamente na terra com mais descanso que neste reino [Portugal] [...] os mesmos escravos índios da terra buscam de comer para si e para os seus senhores e desta maneira não fazem os homens despesa com seus escravos em mantimentos nem com suas pessoas · (Gândavo, 1995: 16/17 [1576]) 
A imagem fornecida por Gândavo foi subscrita e repetida por fontes posteriores. Nos Diálogos das Grandezas do Brasil, o português Brandônio, um alter-ego para o autor, Ambrósio Fernandes Brandão, que foi proprietário de terras em Pernambuco no final do século XVI, afirmava: "a maior parte da riqueza dos lavradores desta terra consiste em terem poucos ou muitos escravos” (1995:213).

Da leitura e da compilação de documentos da época também Pereira da Costa, séculos depois, extraiu uma síntese semelhante: "Não havia branco, por pobre que fosse, que não tivesse vinte ou trinta índios, de que se serviam como cativos, e os ricos tinham aldeias inteiras" (1983:218).

A população nativa estaria enfim inserida nos circuitos coloniais. Mas apesar da enorme redução populacional por que passaram, os indígenas da faixa atlântica não foram extintos ao longo do século XVI, como supõem expectativas e preconceitos ainda vigentes. Estudos recentes realizados por historiadores informam sobre a continuidade da presença indígena na região. As pesquisas realizadas pelos antropólogos na última década identificaram a presença de mais de 60 coletividades que se autoidentificam como indígenas na faixa atlântica e nos sertões do nordeste, incluindo populações litorâneas que foram extensamente objeto de crônicas e de ações coloniais, como os Potiguaras, os Tupinambás e os Tupiniquins (Pacheco de Oliveira, 2004:39-42).

Mesmo sem possuir (algumas delas) um reconhecimento oficial por parte da agência indigenista, tais coletividades continuam a estabelecer entre si redes de intercâmbio e solidariedade, revitalizando suas formas culturais e reafirmando uma identidade própria.

\section{Considerações finais}

A história do Brasil como é habitualmente contada torna inteiramente impossível pretender compreender a importância dos indígenas na fundação da colônia e na construção da nacionalidade, inviabilizando igualmente os esforços de entendimento de sua presença e significação na contemporaneidade. Sem que se exerça sobre ela uma crítica radical, apontando sua ineficácia enquanto instrumento descritivo e analítico, explicitando os pressupostos políticos e ideológicos em que se assenta, instaurando uma perspectiva nova, é impossível compreender os processos atuais de mobilização política, reelaboração cultural e demarcação identitária pela qual passam as populações indígenas da antiga Mata Atlântica brasileira, área onde começou a colonização do país.

Nos pontos relacionados a seguir busco retomar algumas colocações feitas ao longo de minha apresentação, explicitando determinadas implicações teóricas e políticas que afetam os modos de abordagem e as questões contemporâneas quanto aos indígenas. 
Em primeiro lugar, dissemos que para entender a relação entre os índios e o Brasil não basta olhar para o primeiro encontro, ocorrido aqui em Porto Seguro, mas para a formação da colônia, com a instituição do governo-geral e a sua instalação em Salvador. A certidão de nascimento do Brasil, de que nos falava Capistrano de $\mathrm{Abreu}^{14}$, em sua famosa tese de concurso para o Colégio Pedro II, em 1883, não é a carta de Caminha, mas o Regimento de Tomé de Sousa. Não é possível compreender os indígenas atuais ignorando as estruturas estatais que estabeleceram as formas de dominação a que eles foram longamente submetidos.

A magnífica tela que Victor Meirelles pintou, inspirado na carta de Caminha, pode servir como uma imagem metafórica do lugar que a história do Brasil, engendrada no Segundo Reinado, atribuiu aos indígenas. Precedem de fato os portugueses, mas não são propriamente personagens históricos, não passam de testemunhas mudas e desconexas, como a própria natureza que ali circunda os navegadores. A força do turismo, que hoje os exibe nos monumentos e nos hotéis desta cidade, contribui de certo modo para retirar os indígenas de uma invisibilidade crônica nacional e até de uma forte estigmatização local (Grunewald, 2001), mas contribui também para a folclorização dos indígenas, cujos modos de ser são congelados em um eterno primeiro encontro.

Segundo, é preciso sair igualmente de um formalismo jurídico, que pensa o Estado como produto de um contrato social resultante da produção de um consenso entre as partes que o integram. As estruturas políticas da colônia nascente evidenciam-se como violentas, montadas sobre o arbítrio e a exclusão, produtoras por sua vez de novos conflitos e desigualdades. Nada mais distante desta dinâmica do que as autoimagens de uma sociedade tolerante em face das diferenças sociais e étnicas, acionadas frequentemente para celebrar a cordialidade e louvar a suposta democracia racial.

O princípio de toda ação ou política pública será, bem ao contrário, a subordinação do diferente, com a apropriação das terras e dos recursos das populações autóctones. A justificativa permanente e o valor supremo são o de "civilizá-las", construindo sobre elas uma representação profundamente negativa, reprimindo suas línguas e culturas. O melhor modo de administrá-las é homogeneizá-las, produzindo unidades híbridas, favorecendo a assimilação e mantendo sobre elas uma tutela humanitária e religiosa.

Aqui entra em cena o terceiro ponto. Promover a "pacificação" dos nativos, que é o objetivo da ação colonial, é tão somente um estado jurídico-administrativo, não uma descrição sociológica. Implica apenas que, no âmbito de uma circunscrição territorial, um determinado grupo de indígenas não se contraponha mais, por meio de enfrentamentos armados, às autoridades administrativas constituídas. 
A qualificação de "pacificados" só reflete o ponto de vista dos colonizadores, mas nada diz sobre o modo como ocorre a recepção e a utilização de tal ordenamento pelos nativos. A aplicação desta categoria administrativa, de natureza puramente policial-militar, a descrições históricas constitui um crasso erro, ainda maior quando de tal caracterização pretende-se extrair categorias sociológicas ou análises culturais. As perspectivas dualistas, que colocam os indígenas de uma vez para sempre diante do dilema de submeterem-se ou resistirem, de aceitarem a aculturação ou serem exterminados, são completamente equivocadas.

Que grau de refração do comportamento dos nativos diante das normas estipuladas podem os governantes e a elite dirigente aceitar? A tendência é a de que os limites do intolerável se situem na existência de conflitos armados que coloquem em risco a segurança física e patrimonial dos colonizadores, com a invasão ou a destruição de engenhos e fazendas, bem como mortes e ataques aos portugueses. Mas o que sucedeu efetivamente com os indígenas quando em um determinado momento aceitaram a Pax colonial? Embora as crônicas oficiais tendam a sugerir que se trata de um fato marcante e irreversível, frequentemente a pacificação é um procedimento que se repete, uma necessidade recorrente. Em termos estritamente militares, significa apenas que os indígenas reconhecem haver perdido uma batalha e aceitam pagar um preço por isto, mas não implica que a guerra tenha sido concluída e que os vencidos aceitem a sua derrota como final e legítima.

Vejamos um exemplo concreto: os Tupinambás que nos meados do século XVI habitavam a região do Recôncavo baiano. Os que moravam nas cercanias da recémfundada cidade foram arrebanhados pelos missionários jesuítas que acompanharam Tomé de Souza e colocados em aldeias, vindo a configurar a força de trabalho essencial para a nascente colônia. Diversas outras comunidades localizadas mais além, ainda dentro dos limites do Recôncavo, não deixaram jamais de mobilizar-se em ações militares, em articulações políticas entre chefes e em movimentos religiosos (Maestri, 1995).

Embora os governadores a cada vez anunciassem a El Rey (tanto em 1556 quanto em 1558 e 1562) a total submissão dos Tupinambás, os documentos posteriores continuaram a falar de conflitos com eles na mesma região no final do século XVI e também no século XVII. Ocorreu na região, inclusive, o surgimento de fenômenos religiosos (como a "santidade do Jaguaripe", em 1585), que foram reprimidos em função de acarretarem uma maciça fuga de escravos de fazendas vizinhas e em virtude da acusação de que viriam a prejudicar a realização da produção agrícola pelos demais proprietários (vide Vainfas, 1992).

Só a partir do momento em que os fatos possuem gravidade, pois prejudicam seriamente as rotinas e os ganhos de pessoas destacadas dentre os colonizadores, é que são engendrados registros que falam deles e os tornam memoráveis. 
$\mathrm{Na}$ ausência destas condições, quaisquer outras formas de resistência cultural são em geral condenadas ao silêncio e à invisibilidade. O exercício do Direito e da Palavra, como observa De Certeau (2002), é um privilégio dos europeus durante o processo de escrita da história. Isto afeta não só as grandes interpretações, mas também a produção mesma das fontes documentais, o que torna bastante difícil escapar do esquematismo da história oficial e vir a reconstituir o cotidiano das relações entre indígenas e colonizadores.

A categoria de "pacificação" atravessou os cinco séculos da história do Brasil. Ela inspirou no passado a distinção entre, de um lado, os "índios bravos", que deveriam ser objeto de ações de pacificação e que, em caso de resultados negativos, poderiam ter contra si uma declaração oficial de "guerra justa" e, de outro lado, os "índios mansos”, que possuíam direitos e obrigações enquanto vassalos do rei. (Figuras 6 e 7$)$

Ainda muito recentemente, duas ou três décadas atrás, a categoria de "pacificação" era de uso corrente entre os mais destacados sertanistas da agência indigenista, ${ }^{15}$ estando associada a um conjunto de preceitos e técnicas quanto à atração de indígenas classificados como "isolados" ou "arredios (ao contato)". No polo oposto dessa classificação, estava a categoria de "integrado”, aplicável aos indígenas que, assimilados à sociedade nacional, estariam no limiar da perda de sua condição étnica. Tal tipologia, formulada em documentos administrativos do antigo SPI, veio a figurar no Estatuto do Índio (1973), adquirindo até certo respaldo de conceituados antropólogos. Revela-se, porém, como herdeira da velha polaridade colonial acima descrita.

Pacificação e civilização são faces distintas de um mesmo processo, que tiveram/ têm como finalidade a perda de autonomia e a introdução de dependências da coletividade indígena em relação a bens e serviços que lhes eram exteriores, tornando-as sujeitas ao exercício de um mandato tutelar.

Um quarto equívoco dessa narrativa colonial é a instauração de uma clivagem radical e definitiva entre índios e não-índios, formatados segundo um padrão apenas disjuntivo que não admite misturas, sobreposições ou alternâncias, ou seja, índios e brancos são conceituados como tipos absolutamente distintos e polarizados em termos de atitudes e valores, uma dualidade inspirada no modelo religioso do pagão x cristão.

É em decorrência de tal parâmetro ideológico que as populações autóctones serão reiteradamente representadas a partir da imagem do "índio bravo", pois tais avaliações estão sempre relacionadas à condição tutelar que ocuparam (e ocupam) em diferentes projetos nacionais. Daí a virtual inexistência de registros sobre famílias e coletividades indígenas que optaram por viver dentro da sociedade co- 
32 O Nascimento do Brasil

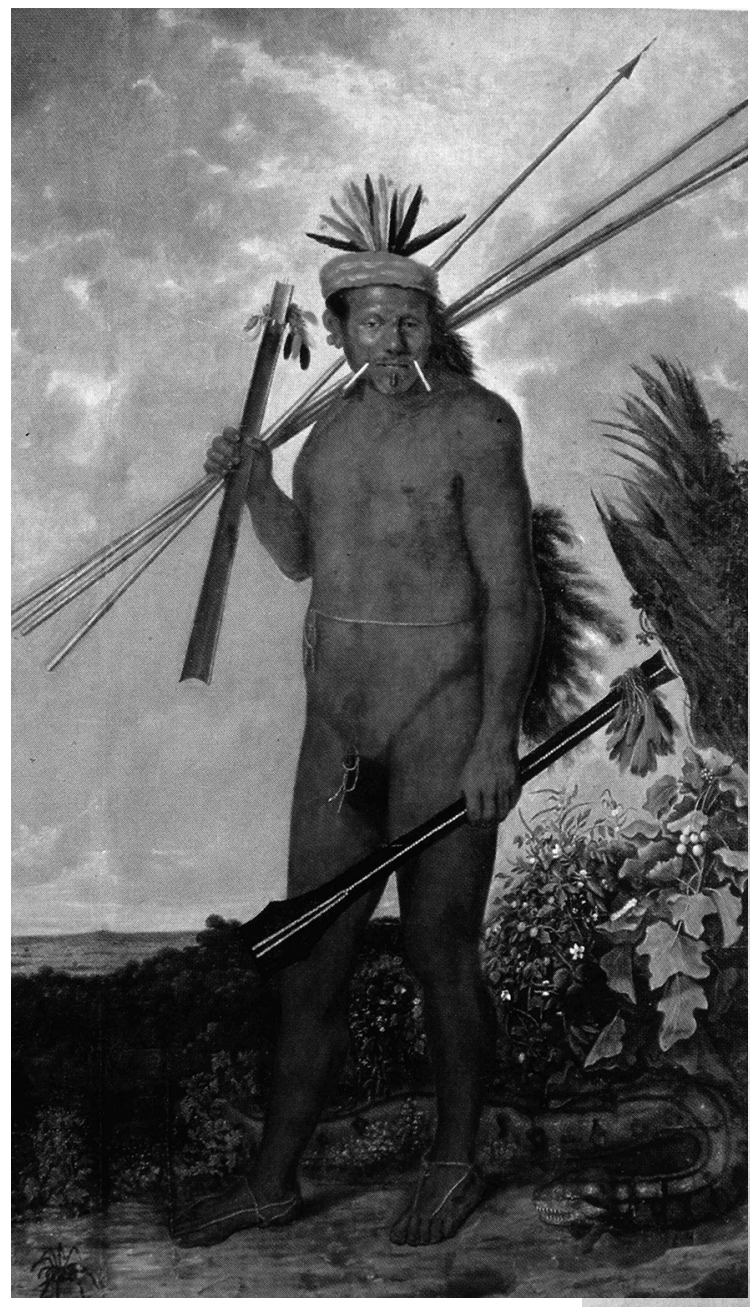

Figuras 6

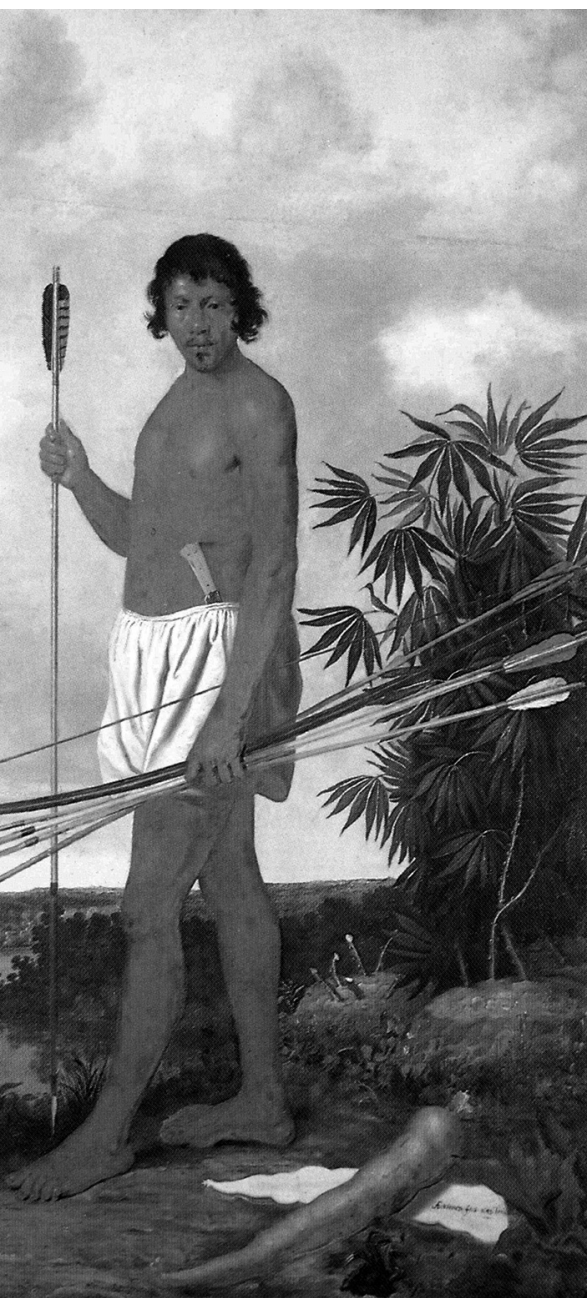

Figura 7 
lonial. Uma vez que mantinham relações pacíficas com os brancos e não evidenciavam explicitamente o estabelecimento de linhas de continuidade com tradições autóctones que ofendiam ou ameaçavam os colonizadores, a especificidade de suas formas socioculturais era automaticamente negada e declarada inexistente.

A incorporação de indígenas a famílias de descendentes de portugueses era algo estritamente individual, sobre a qual as convenções sociais recomendavam não falar, que em nada afetava as categorizações grupais e coletivas. Em consequência, isto não se traduzia no reconhecimento da mestiçagem nem em uma suposta diminuição de clivagens étnico-raciais, mas sim na acentuação dos estigmas. Os indígenas que se associavam aos brancos através do casamento ou da adoção eram estimulados a renegar sua condição pretérita (que só lhes acarretava prejuízos e discriminações), transmitindo tal atitude aos seus descendentes.

Em decorrência deste fato, o indígena tem sido pensado no Brasil como perfeitamente solúvel na colonização. O seu destino seria a convivência quase perfeita com os brancos, a invisibilidade dentro da sociedade brasileira. As trajetórias individuais não excluem a permanente refabricação do estigma e da segregação.

Por último, o quinto e mais importante ponto. Todas as narrativas e as interpretações produzidas pela história oficial sobre os indígenas desconhecem por completo a especificidade dos seus pontos de vista e suas estratégias. Não buscam em momento algum de sua análise situar-se na perspectiva dos indígenas, mas falam sempre de um prisma absolutamente exterior.

Assim, todos os discursos em seus esforços de totalização passam necessariamente pela polaridade proteção x extermínio, que presidiu a criação do SPI e ainda hoje assegura as demarcações cruciais do campo político indigenista. Não importa a que período histórico, região ou etnia o narrador esteja se referindo, sempre todos os personagens, leis e eventos que surgem nesse relato devem ser agrupados em função da condição de protetores ou de predadores de índios.

Essa dualidade, apontada por Souza Lima (1995) para o sertanismo rondoniano e o indigenismo proposto por Darcy Ribeiro, remonta de fato aos primeiros escritos dos jesuítas no Brasil. Torna-se muito mais rígida e impositiva no século XVII (sobretudo com os escritos do padre Antonio Vieira) e irá nortear todas as narrativas históricas subsequentes, atingindo o século XX e estendendo-se aos dias atuais.

É importante ter presente que os relatos coloniais, mesmo de missionários em aberta oposição aos colonos, pouco se empenharam em destruir, anular ou reformular as avaliações negativas sobre os indígenas. As crônicas do século XVI destacavam primordialmente os fatores e os costumes que diferenciavam radicalmente portugueses e autóctones. Ratificavam a necessidade de conversão e tutela dos in- 
dígenas, valorizando o empreendimento a que eles se dedicavam.

Diferentemente do que poderia parecer a uma visão polarizadora que vimos criticando, a atividade missionária e as ações punitivas caminharam juntas no século XVI e se integraram como constitutivas da conquista das populações autóctones e da implantação da ordem colonial. Tanto os missionários quanto os colonos estão referidos a um mesmo problema - a disputa sobre o controle do trabalho indígena - e procedem de um mesmo solo jurídico e ideológico, onde a "civilização" do índio (entenda-se aqui sua submissão política, sua utilização como trabalhador e a salvação de sua alma pela catequese) era vista como um valor e uma necessidade. A convergência de interesses levou a uma aparente unidade das fontes quanto à caracterização dos indígenas, que eram assim como "naturalmente" refratários ao trabalho, virtualmente "perigosos" e necessitando de tutela e civilização.

Tal polaridade entre proteção x extermínio não se expressará somente ao longo da história na oposição missionários x colonos, mas também em outros pares (como jesuítas $\mathrm{x}$ outras ordens religiosas, missionários $\mathrm{x}$ bandeirantes, missionários $\mathrm{x}$ diretores de índios no período Pombalino). Continuará a impor-se no período republicano com a polaridade militares x extrativistas, e já no período da FUNAI nos confrontos entre funcionários da agência tutelar ("indigenistas autênticos" x "burocratas e desenvolvimentistas"). Até mesmo no contexto pós-tutelar permanece a tendência a classificar os agentes históricos como "indigenistas" e "anti-indígenas", colocando no primeiro bloco atores absolutamente distintos, que vão desde funcionários governamentais até os quadros das ONGs e das agências internacionais.

Classificar desta forma maniqueísta e simplória as ações e os episódios em que estão envolvidos os indígenas não leva a uma compreensão efetiva do espaço político que eles ocupam hoje e ocuparam no passado com múltiplas formas de resistência, inviabilizando igualmente qualquer expectativa (atual ou futura) quanto ao seu protagonismo. Ao assim proceder, tal discurso revela-se como peça fundamental para legitimar a tutela, naturalizando-a, e persistindo em ignorar as vozes e as iniciativas dos indígenas reais.

Em síntese, procurei aqui apontar como estão defasadas e são inoperantes as categorias analíticas derivadas de modelos jurídicos coloniais, foco de nossa breve incursão histórica.

Estamos em terras dos Pataxós, Tupinambás e Tupiniquins! Reconhecer isto não é invalidar toda a história que veio depois, é buscar corrigi-la. Não se constroem cidadanias dentro de nações modernas declarando aleatórias ou inexistentes as marcas e os destinos sociais de vencidos e vencedores, de descendentes de senhores e de escravos, de seguidores de religiões oficiais ou perseguidas.

Os tempos atuais exigem outros instrumentos de convivência social, que apos- 
tem não na repressão e sim na participação. Instrumentos que tenham como desafio superar as exclusões sociais, incorporar em estruturas plurais os diferentes. Os indígenas tiveram - e terão, acredito - um papel importante nesse processo.

\section{Notas}

*Conferência realizada na XXVI Reunião Brasileira de Antropologia, Porto Seguro (Ba), em 02 de junho de 2008

1. $\mathrm{Na}$ elaboração desta conferência apoiei-me especialmente em dois trabalhos que desenvolvi anteriormente. A primeira foi uma pesquisa histórica e de imagens voltada para a preparação da exposição “Os Primeiros Brasileiros” (vide Pacheco de Oliveira, 2007), durante período como professor-visitante da Fundação Joaquim Nabuco, contando o apoio do CNPq. A segunda foi um extenso artigo, intitulado "Os indígenas na fundação da colônia: Uma abordagem crítica”, a sair no livro O Brasil Colonial (Fragoso \& Gouveia [orgs.], no prelo).

2. Um exemplo impressionante disso é o relato de Gabriel Soares de Sousa (2000).

3. "Omiti fazer uma observação a VV. Excas, e é - que a tranquilidade e conservação do Brasil dependem, em parte, das relações de amizade com os índios [...]” (Nassau, 1906).

4. Tal mapa integra o Atlas intitulado Estado do Brasil, feito em 1631 pelo cosmógrafo João Teixeira Albernas, contendo 36 pranchas coloridas, com medidas em média de 60 x $40 \mathrm{~cm}$. Tal trabalho lhe foi encomendadopelo conde Dom Jerônimo deAtaíde, desde 1629 donatário da Capitania de Ilhéus, depois Governador Geral de 1653 a 1657. A tarefa foi entregue a um dos expoentes da cartografia portuguesa, que atuou por longos anos no Armazém de Guiné e das Índias, organismo governamental encarregado de fornecer navios ao Rei e à Casa da Índia, bem como de elaborar as cartas de ofício e estabelecer os padrões cartográficos. Não se tratava, portanto, de uma cartografia de divulgação, que buscasse fantasias e exotismos próprios ao imaginário europeu, mas de um mapa de Estado, preocupado com rigor e exatidão, servindo de orientação a navegadores, militares e governantes (vide Guerra \& Duarte dos Santos, 2008:293-305).

5. Entre outros estudos sobre o IHGB, vide em especial Kodama (2009).

6. Foi organizada em 01/10/1550 uma recepção ao rei na cidade de Rouen, na qual o tema foi a reconstituição da vida em uma aldeia tupi do Brasil (vide Dennis, 1944).

7. O impacto dessas viagens, das encenações promovidas e dos livros de viagem se fizeram sentir sobre o pensamento francês, sendo Montaigne o primeiro de uma genealogia que desembocaria no Iluminismo com Rousseau e a teoria da bondade natural. Há uma extensa bibliografia sobre o tema, limitando-me aqui a referir dois autores: Melo Franco (1976) e Pagden (1982).

8. "Porém o melhor fruto que dela se pode tirar me parece que será salvar essa gente. 
E esta deve ser a principal semente que Vossa Alteza nela deve lançar” (Castro, op. cit.:116).

9. Soares, Francisco. 1596. Cousas mais notáveis do Brasil e de alguns costumes de seus índios apud Couto, 1995, op. cit.: 276-277.

10. Os dados que serão aqui utilizados relativos à população indígena referem-se apenas aos índios "forros", residentes nas aldeias missionárias. Não existem dados gerais relativos aos indígenas "cativos", o que dificulta ao extremo os exercícios de demografia histórica no mundo colonial brasileiro. As pesquisas existentes são localizadas e partem de inventários e documentos diversos (ver nesse sentido Monteiro, 1994).

11. Vide carta de 1532 de Diogo Gouveia a D. João III, de quem era conselheiro, delineando propostas sobre a colonização privada do Brasil e a oportunidade de existirem casamentos entre os naturais do reino e mulheres indígenas, de modo a acelerar o povoamento e a multiplicação de vassalos (Couto, op. cit.:218).

12. Os mais influentes catequistas do século XVI, Nóbrega e Anchieta, expressaram em diversas cartas sua crença de que a "guerra justa” contribuía efetivamente para a conversão do gentio.

13. A satanização das religiões, o horror à antropofagia e ao espírito guerreiro dos indígenas transparecem muito fortemente nas crônicas de missionários e viajantes da $2^{\mathrm{a}}$. metade do século XVI. As representações gráficas que correram o mundo apresentam os indígenas do Brasil como ferozes canibais (Vide Raminelli, 1996 e Lestringant, 1997).

14. Capistrano de Abreu, 1932:190-191.

15. Uma cuidadosa análise do discurso dos sertanistas pode ser encontrada em Rocha Freire (2005). 


\section{Referências bibliográficas}

ANCHIETA, José. 1988. Cartas, Informações, Fragmentos Históricos e Sermões (15541594). Belo Horizonte/São Paulo: Itatiaia/Edusp, 1988.

BELluZZO, Ana Maria de Morais (org.). 2000. O Brasil dos Viajantes. São Paulo: Objetiva/ Metalivros.

BRANDÃO, Ambrósio Fernandes. 1997[1618]. 3. ed. Diálogo das Grandezas do Brasil. Organização e Introdução de José Antonio Gonsalves de Mello. Fundação Joaquim Nabuco/Editora Massangana.

CAPISTRANO DE ABREU, J. 1932. "Prefácio à História do Brasil”. In Ensaios e Estudos (Crítica e História). Rio de Janeiro, Livraria Briguiet: 173-199.

CASTRO, Sílvio (org).1985. A Carta de Pero Vaz de Caminha. Descobrimento do Brasil.

S. Castro (Introdução, atualização e notas). Porto Alegre: L\&PM.

COUTO, Jorge. 1995. A Construção do Brasil. Lisboa: Edições Cosmos.

DE CERTEAU, Michel. 2002. A Escrita da História. Rio de Janeiro: Forense Universitária.

DENNIS, Ferdinand. 1944. Uma festa brasileira. Rio de Janeiro.

GÂNDAVO, Pero de Magalhães. 1995. Tratado da Província do Brasil \& História do Brasil. Recife: Fundação Joaquim Nabuco/Editora Massangana.

GRUNEWALD, Rodrigo de Azeredo. 2001. Os Índios do Descobrimento. Tradição e Turismo. Rio de Janeiro: Contra Capa.

GUERRA, Amanda Estela \& DUARTE DOS SANTOS, Márcia Maria. 2008. "O Atlas 'Estado do Brasil': um olhar português sobre a América Colonial”. Revista Brasileira de Cartografia, 60(03):293-305, outubro.

KODAMA, Kaori. 2009. Os Índios no Império do Brasil: a etnografia do IHGB entre as décadas de 1840 e 1860. Rio de Janeiro/São Paulo: Editora Fiocruz/EDUSP. 
LESTRINGANT, Frank. 1997. O canibal: Grandeza e decadência. Tradução Mary Lucy Murray Del Priore. Brasília: Editora UNB.

MAESTRI, Mario. 1995. Os senhores do litoral: conquista portuguesa e agonia Tupinambá no litoral brasileiro (século 16). Porto Alegre: Editora da Universidade/UFRGS.

MARCHANT, Alexander. 1980. Do Escambo à Escravidão: As relações econômicas de portugueses e índios na colonização do Brasil (1500-1580). São Paulo/Brasília: Companhia Editora Nacional/INL. p. 95.

MELO FRANCO, Afonso Arinos. 1976. O Índio Brasileiro e a Revolução Francesa: As origens brasileiras da teoria da bondade natural. Rio de Janeiro: José Olympio.

MONTEIRO, John M. 1994. Negros da Terra: Índios e Bandeirantes nas Origens de São Paulo. São Paulo: Companhia das Letras.

NASSAU, Mauricio de. 1906, junho. Relatório aos Estados Gerais, ao retornar à Holanda. Revista do Instituto Archeologico e Geographico Pernambucano, vol. XII, n. 68.

PACHECO DE OLIVEIRA, João. 2004. “Uma etnologia dos 'índios misturados'? Situação colonial, territorialização e fluxos culturais”. In: (org.). A Viagem da Volta: Etnicidade, política e reelaboração cultural no Nordeste Indígena. 2. ed. Rio de Janeiro: Contra Capa: 13-42. . 2007. "Os Primeiros Brasileiros". Catálogo de Exposição. São Paulo: SESC. . (no prelo). “ Os indígenas na formação da colônia. Uma abordagem crítica”. In FRAGOSO, João \& GOUVEIA, Fátima (orgs.). O Brasil Colinial. Rio de Janeiro: Record.

PAGDEN, Anthony. 1982. The Fall of Natural Man: the American Indian and the Origins of Comparative Ethnology. Cambridge: Cambridge University Press. 
PEREIRA DA COSTA, F. A. 1983. Anais Pernambucanos. Vol.VI. Recife: FUNDARPE.

RAMINELLI, Ronald. 1996. Imagens da colonização: a representação do índio de Caminha aVieira. Rio de Janeiro: Jorge Zahar.

ROCHA FREIRE, Carlos Augusto da. 2005. Sagas sertanistas. Tese de Doutorado em Antropologia Social, PPGAS/Museu Nacional, Rio de Janeiro.

SCHWARTZ, Stuart B. 1988. Segredos Internos: Engenhos e Escravos na Sociedade Colonial - 1550/1835. São Paulo: Companhia das Letras.

SOARES DE SOUSA, Gabriel. 2000. Tratado Descritivo do Brasil em 1587. Recife: Fundação Joaquim Nabuco/Editora Massangana.

SOUSA, Gabriel Soares de. 2000. - Tratado Descritivo do Brasil em 1587. Recife: Fundação Joaquim Nabuco/Editora Massangana.

SOUZA LIMA, Antonio Carlos. 1995. Um grande cerco de paz: poder tutelar, indianidade e formação do Estado do Brasil. Petrópolis: Vozes/ANPOCS.

STADEN, Hans. 1974[1557]. Duas viagens ao Brasil. Belo Horizonte/São Paulo: Itatiaia/Edusp. pp. 47-51.

VAINFAS, Ronaldo. 1992. "Idolatrias luso-brasileiras: as santidades indígenas”. In: (org.). América em tempo de conquista. Rio de Janeiro: Jorge Zahar.

VARNHAGEN, Francisco Adolfo de. 1978[1854]. História Geral do Brasil antes de sua separação e independência de Portugal. 3 vols. São Paulo: Melhoramentos. 


\section{Resumo}

A história do Brasil como é habitualmente contada torna inteiramente inviável pretender compreender a importância dos indígenas na fundação da colônia bem como na construção da nacionalidade. Sem que se exerça sobre ela uma crítica radical, apontando sua ineficácia enquanto instrumento descritivo e analítico, explicitando os pressupostos políticos e ideológicos em que se assenta, rompendo com o paradigma historiográfico existente, é impossível compreender os processos atuais de mobilização política, re-elaboração cultural e demarcação identitária pela qual passam as populações indígenas do nordeste, área onde começou a colonização do país. A categoria de "pacificação", que constituiu um dos pilares básicos da política colonial e ainda hoje se expressa na classificação dos indígenas segundo um gradiente que vai de "isolados" a "integrados", só tem valor militar e administrativo, não analítico. As narrativas e interpretações produzidas pela história oficial sobre os indígenas desconhecem por completo a especificidade dos seus pontos de vista e de suas estratégias. Classificam de forma maniqueísta, através da oposição extermínio e proteção, as ações e episódios em que estão envolvidos os indígenas sem chegar a uma compreensão efetiva do espaço político que ocuparam e das múltiplas formas de resistência que colocaram em prática. Ao assim proceder tal discurso revela-se como peça fundamental para legitimar a tutela, naturalizando-a, e persistindo em ignorar as vozes e iniciativas dos indígenas reais.

\section{Palavras-chave}

Antropologia Histórica, Índios do Nordeste, Guerra de Conquista, Formação do Brasil-Colônia; Categorias e saberes coloniais.

\begin{abstract}
History of Brazil, as usually narrated, make impossible to understand the real importance of the Indigenous Peoples both in the colony' $\mathrm{s}$ foundation and in the construction of national identity. The paper stress the urgency of submitting this narrative to a radical criticism in descriptive and analytic terms. Making use of historic and ethnographic data about those called Northeastern Indians, people who suffered the first impact of European colonization, I argue it is impossible to explain the present processes of political mobilizations and cultural empowerment without confronting this ethnocentric and equivocal narrative, and , breaking the historiographic paradigm that supports this discourse.
\end{abstract}

\section{Key words}

Historic Anthropology; Northeastern Indians; War of Conquest; Process of NationBuilding; Colonial Thinking and Categories. 